\title{
Improvement in Blast Furnace Reaction Efficiency through the Use of Highly Reactive Calcium Rich Coke
}

\author{
Seiji NOMURA, Hiroyuki AYUKAWA, ${ }^{1)}$ Hisatsugu KITAGUCHI, ${ }^{2)}$ Toshihide TAHARA, ${ }^{3)}$ \\ Shinroku MATSUZAKI, Masaaki NAITO, Satoshi KOIZUMI, ${ }^{1)}$ Yoshikuni OGATA, ${ }^{1)}$ \\ Takeshi NAKAYAMA ${ }^{11}$ and Tetsuya ABE ${ }^{11}$
}

Environment \& Process Technology Center, Nippon Steel Corporation, 20-1, Shintomi, Futtsu, Chiba $293-8511$ Japan. E-mail: s-nomura@re.nsc.co.jp 1) Hokkai Iron \& Coke Corp., 12 Nakamachi, Muroran, Hokkaido 050-0087 Japan. 2) Advanced Technology Research Laboratories, Nippon Steel Corporation, 20-1, Shintomi, Futtsu, Chiba $293-8511$ Japan.

3) Kimitsu Works, Nippon Steel Chemical Co., Ltd., 1, Kimitsu, Kimitsu, Chiba 299-1196 Japan.

(Received on October 20, 2004; accepted in final form on January 7, 2005)

\begin{abstract}
A method to produce coke in 'lump' form with high strength and reactivity through the addition of a catalyst was investigated in order to improve blast furnace reaction efficiency. The addition of Ca compounds to coal before carbonization was found to considerably increase the reactivity of the coke at a low temperature range in the thermal reserve zone of a blast furnace. Furthermore it was proved that strong, highly reactive 'lump' form coke could be produced by adding a Ca-rich non-caking coal and adjusting the coal blend composition. Based on this fundamental study, the Ca-rich coke was successfully produced in coke ovens on a commercial scale, both at Kimitsu and Muroran works. The use of the Ca-rich coke in the Muroran No. 2 blast furnace was found to cause a decrease in the reducing agent rate by $10 \mathrm{~kg} / \mathrm{t}-\mathrm{p}$. This technology, producing coke of high reactivity and strength through catalyst addition, is promising as a means of improving the reaction efficiency of a blast furnace.
\end{abstract}

KEY WORDS: coke reactivity; catalyst; ironmaking; reaction efficiency; blast furnace; thermal reserve zone.

\section{Introduction}

Any improvement in the blast furnace reaction efficiency during the blast furnace ironmaking process is very significant, since it has the potential to allow a decrease in the reducing agent rate (the amount (in $\mathrm{kg}$ ) of reducing agents such as coke and coal needed to produce $1000 \mathrm{~kg}$ of pig iron) as well as $\mathrm{CO}_{2}$ emissions. Naito et al. ${ }^{1)}$ proposed a technology which drastically improves reaction efficiency in the blast furnace by decreasing the temperature of the thermal reserve zone through the use of highly reactive coke. Here the reactivity of coke refers to the reaction rate of coke with $\mathrm{CO}_{2}\left(\mathrm{C}+\mathrm{CO}_{2}=2 \mathrm{CO}\right){ }^{2)}$ It was reported that the use of highly reactive 'nut' coke in a commercial scale blast furnace improved the reaction efficiency ${ }^{3)}$ and decreased the temperature of the thermal reserve zone. ${ }^{4)}$ It is therefore expected that increased reactivity in normal or 'lump' form coke, representing the majority of the coke used in a blast furnace, will improve its efficiency to a greater extent. However, no practical methods have yet been devised to produce the 'lump' form of coke with high reactivity and strength. The focus here, therefore, is on the potential production method for 'lump' coke demonstrating such qualities in a commercial coke oven.

The reactivity of 'lump' coke is considered to depend on its chemical reactivity and pore diffusion ${ }^{5)}$ respectively, as shown in Fig. 1. The chemical reactivity of coke depends on its individual carbon structure and the catalytic effect of the internal mineral components. In order to decrease the temperature of the thermal reserve zone, it is important to increase the coke reactivity at a low temperature range, namely the chemical reactivity of the coke. The carbon structure depends on factors such as the coke oven temperature and the types of coals used. It is understood that a decrease in the oven temperature leads to a corresponding decrease in the degree of graphitization (crystallite size, $L_{\mathrm{c}}$ ), which in turn, leads to a high level of chemical reactivity. ${ }^{6}$ ) It is also known that the types of coke texture vary according to the types of coals used and that the optically isotropic coke texture is more reactive than the anisotropic texture. ${ }^{6}$ ) However, in terms of the operation of a coke oven for the production of blast furnace coke on a commercial scale, considerably increasing the chemical reactivity of coke through adjustment of these factors alone is difficult. Therefore, we tried to increase the coke chemical reactivity by instead making use of the catalytic effect. ${ }^{7)}$

The questions to be answered when implementing this method are 1) how the catalyst is added to the coke and 2) what kinds of compounds are suitable as a catalyst. There are considered to be two basic methods of adding the catalyst to the coke. The first method is 'post-addition of catalyst to coke', as shown in Fig. 2, where the catalyst and/or catalyst solution is sprayed onto the coke after the coke is pushed out of a coke oven chamber. The second method is 


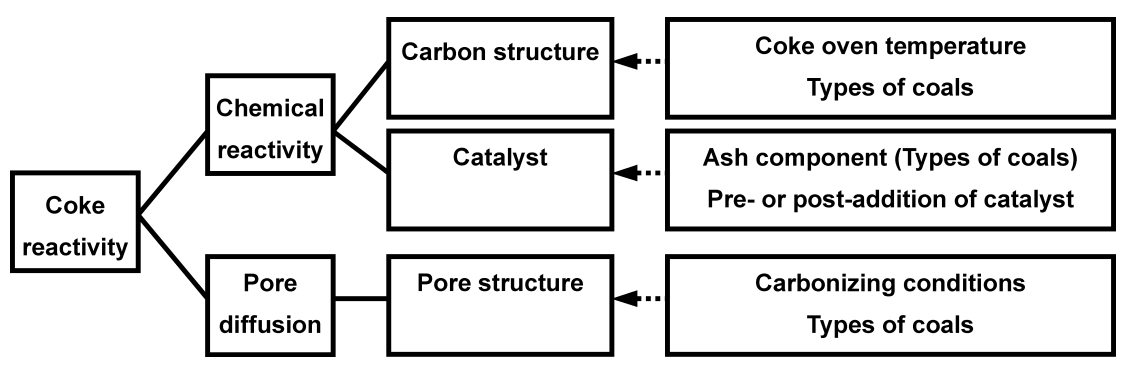

Fig. 1. The factors determining coke reactivity.

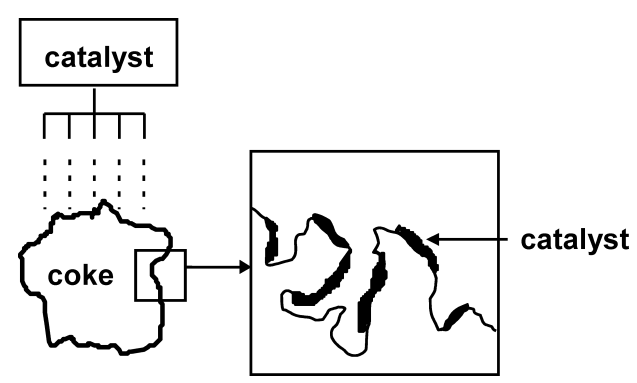

Fig. 2. 'Post-addition of catalyst to coke' method.

'pre-addition of catalyst to coke', as shown in Fig. 3, where that catalyst is mixed with coal before the mixture is carbonized in a coke oven chamber. Adjustment of the ash components through coal selection is also part of the latter method. The internal distribution of catalyst in the coke differs in both methods; the former involving the catalyst mainly on the surface of the coke while in the latter, it exists almost homogeneously in the coke. In this report, the latter method of 'pre-addition of catalyst to coke' was investigated. The former method is now being studied and it will be interesting to compare the highly reactive cokes produced in both methods because the homogeneousness of catalyst in the coke may affect the reaction behavior of the coke.

Although it is known that alkali metal, alkaline earth metal and transition metal have high catalytic activity during the $\mathrm{C}-\mathrm{CO}_{2}$ reaction, ${ }^{8)}$ there are relatively few quantitative data concerning the reactivity of blast furnace coke containing these catalysts in the atmosphere of the thermal reserve zone in a blast furnace. Moreover, no practical methods have been proposed to produce a 'lump' form of coke with high reactivity and strength in a commercial coke oven.

Alkali metal is undesirable as a catalyst because its presence in coke generates the development of scaffolding on the blast furnace wall. Fe (iron), which is one of the typical transition metals, is also undesirable when considering the 'pre-addition of catalyst to coke' method, since $\mathrm{FeO}$ may react with $\mathrm{SiO}_{2}$, namely the main component of the coke oven wall brick, during carbonization, producing a low melting compound, fayalite $\left(2 \mathrm{FeO} \cdot \mathrm{SiO}_{2}\right)$ and damaging the wall brick. Therefore, we tested the alkaline earth metal (mainly $\mathrm{Ca}$ and $\mathrm{Mg}$ ) compounds as catalysts, since large quantities are used as raw materials in the ironmaking process with the blast furnace and they are also included in coal.

First, various kinds of alkaline earth metal compounds were added to the coke using the "pre-addition of catalyst to

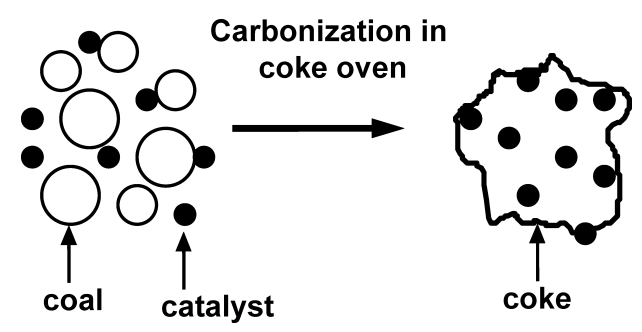

Fig. 3. 'Pre-addition of catalyst to coke' method.

coke' method and the chemical reactivity of the coke was then studied. Consequently, the high rate of catalytic activity of the Ca became apparent. We then proceeded to investigate a potential means of producing coke with high reactivity and strength by adding Ca-rich coal to charged coals in laboratory and commercial scale tests. Finally, Ca-rich coke was produced in the commercial scale coke oven at the Muroran works from June to September of 2002 and all the coke was used in the Muroran No. 2 blast furnace.

\section{Basic Study Concerning the Production Method of Coke with High Reactivity and Strength}

\subsection{Experimental}

\subsubsection{Sample Used}

Six types of coals (Table 1, coals A-F) were used in the test. Coals A and B are caking coals, usually used for making blast furnace coke. Coal C is of low rank (vitrinite average reflectance $\leqq 0.8$ ) and low fluidity ( $\log$ (maximum fluidity/ddpm) $\leqq 2.5$ ) coals. Here, this type of coal is described as a low rank and slightly caking coal, abbreviated as "SCC". Coals D, E and F are non-caking coals which show no fluidity. Coal $\mathrm{F}$ contains a large amount of $\mathrm{Ca}$ (Ca-rich coal). In addition, in order to investigate the effect of the alkaline earth metal addition on the coke reactivity, five compounds $\left(\mathrm{SrCO}_{3}, \mathrm{CaCO}_{3}, \mathrm{MgCO}_{3}, \mathrm{CaO}\right.$ and $\left.\mathrm{MgO}\right)$ were used.

\subsubsection{Carbonization Test}

\section{(1) Addition of Alkaline Earth Metal Compound}

In order to study the effect of the alkaline earth metal compound addition on the coke chemical reactivity, the coal/alkaline earth metal compound mixtures were carbonized in an electrically heated test coke oven. ${ }^{9)}$ Coals B and $\mathrm{C}$ were crushed to $80 \%<3 \mathrm{~mm}$ and a blended coal was then prepared by mixing coals B and C (coal B 70\%, coal C $30 \%$ ). The moisture content was $4 \%$. After various kinds of alkaline earth metal compound were added to the blended coal at an addition rate of 2.5 to 7.5 mass $\%$, the sample was charged in a steel box (420 mm wide, $600 \mathrm{~mm}$ long and $400 \mathrm{~mm}$ high) at a bulk density of 830 dry $-\mathrm{kg} / \mathrm{m}^{3}$. The box 
Table 1. Characterization data for the coals used.

\begin{tabular}{|c|c|c|c|c|c|c|c|c|c|c|c|c|c|}
\hline \multirow{2}{*}{ Coal } & \multicolumn{2}{|c|}{$\begin{array}{c}\text { Proximate } \\
(\text { mass } \% \mathrm{db})\end{array}$} & \multirow{2}{*}{$\begin{array}{c}\text { Total } \\
\text { dilatation } \\
\text { (vol. } \%)\end{array}$} & \multirow{2}{*}{$\begin{array}{c}\text { Maximum } \\
\text { fluidity } \\
(\log \text { MF/ddpm) }\end{array}$} & \multirow{2}{*}{$\begin{array}{c}\text { Reflectance } \\
\text { (av.)( \%) }\end{array}$} & \multicolumn{8}{|c|}{ Major ash component (\%) } \\
\hline & VM & Ash & & & & $\mathrm{P}_{2} \mathrm{O}_{5}$ & $\mathrm{~K}_{2} \mathrm{O}$ & $\mathrm{Na}_{2} \mathrm{O}$ & $\mathrm{SiO}_{2}$ & $\mathrm{Al}_{2} \mathrm{O}_{3}$ & $\mathrm{Fe}_{2} \mathrm{O}_{3}$ & $\mathrm{CaO}$ & $\mathrm{MgO}$ \\
\hline $\bar{A}$ & 20.7 & $\overline{9.8}$ & 99 & 2.56 & 1.42 & 0.74 & 1.12 & 0.83 & 59.99 & 26.66 & 4.20 & 1.42 & 0.59 \\
\hline B & 23.8 & 8.8 & 103 & 2.93 & 1.28 & 0.45 & 1.07 & 0.75 & 56.40 & 31.48 & 3.70 & 0.87 & 0.59 \\
\hline C & 35.7 & 9.1 & 32 & 2.08 & 0.79 & 0.41 & 1.14 & 0.51 & 62.98 & 23.83 & 4.99 & 1.52 & 0.76 \\
\hline D & 43.2 & 4.7 & 0 & - & 0.63 & 0.38 & 2.22 & 0.52 & 55.72 & 22.43 & 9.66 & 2.85 & 1.66 \\
\hline$E$ & 48.6 & 1.7 & 0 & - & 0.44 & 0.31 & 0.77 & 0.39 & 39.38 & \begin{tabular}{|l|}
19.72 \\
\end{tabular} & 18.04 & 6.56 & 1.69 \\
\hline $\mathbf{F}$ & 37.4 & 5.3 & 0 & - & 0.61 & 0.08 & 0.13 & 1.47 & 21.23 & 9.18 & 6.07 & 45.99 & 1.34 \\
\hline
\end{tabular}

Table 2. The blending composition of the coals.

\begin{tabular}{|c|c|c|c|c|c|c|c|c|c|}
\hline \multirow{2}{*}{ Coal } & \multicolumn{9}{|c|}{ Test } \\
\hline & 1 & 2 & 3 & 4 & 5 & 6 & 7 & 8 & 9 \\
\hline$\overline{\mathbf{A}}$ & & & & 20 & 20 & 20 & 20 & 20 & 20 \\
\hline B & 70 & 90 & 80 & 50 & 50 & 50 & 50 & 50 & 50 \\
\hline C & 30 & & & 30 & 25 & 20 & 15 & 20 & 20 \\
\hline $\bar{D}$ & & & & & & & & 10 & \\
\hline $\bar{E}$ & & & & & & & & & 10 \\
\hline$F$ & & 10 & 20 & & 5 & 10 & 15 & & \\
\hline
\end{tabular}

was then placed in an electrically heated test oven and carbonized for $18.5 \mathrm{~h}$ under heating conditions equivalent to the flue temperature of $1250^{\circ} \mathrm{C}$ in an actual coke oven.

\section{(2) Addition of Ca-rich Coal}

In order to study the effect of adding Ca-rich coal to charged coals on the coke reactivity and strength, coals were crushed to $85 \%<3 \mathrm{~mm}$ and blended as shown in Table 2, with a moisture content of $3 \%$. The blended coals were then charged in a steel box at a bulk density of 850 dry $-\mathrm{kg} / \mathrm{m}^{3}$. In tests 1,2 and 3, the blending ratio of coal F was 0,10 and $20 \%$ respectively and the changes in the coke reactivity by blending coal $\mathrm{F}$ were examined. In Tests 4 to 7 meanwhile, the effect of substituting coal $\mathrm{F}$ for coal $\mathrm{C}$ on coke reactivity and strength was studied, where the blending ratio of coal $\mathrm{C}$ was decreased from 30 to $15 \%$ while that of coal $\mathrm{F}$ was increased from 0 to $15 \%$. In Tests 8 and 9 , the effect of substituting coals $\mathrm{D}$ and $\mathrm{E}$ for coal $\mathrm{F}$ on coke reactivity and strength was studied, where coals D and $\mathrm{E}$ were used instead of coal $\mathrm{F}$ in Test 6.

\subsubsection{Coke Quality Measurement}

\section{(1) Coke Strength}

After the coke was quenched with nitrogen, the coke sample was stabilized by the drop shatter test apparatus, $\left.{ }^{10}\right)$ where the sample was dropped from the position of $2 \mathrm{~m}$ high, three times. The JIS drum index of coke (DI ${ }^{150}{ }_{15}$, a percentage of coke mass retained on sieves with $15 \mathrm{~mm}$ apertures to the original mass of the coke sample after 150 revolutions in the JIS drum tester) ${ }^{10)}$ was measured.

\section{(2) Coke Reactivity}

The JIS coke reactivity index (JIS $\left.\mathrm{R}_{\mathrm{e}} \mathrm{I}\right){ }^{10)}$ which stands for the chemical reaction rate of coke with $\mathrm{CO}_{2}$ at a low temperature range, was measured as a means of evaluating the chemical reactivity of coke. In this method, $10 \mathrm{~g}$ of $0.85-1.7 \mathrm{~mm}$ coke breeze is reacted with $\mathrm{CO}_{2}$ at $950^{\circ} \mathrm{C}$ and JIS $\mathrm{R}_{\mathrm{e}} \mathrm{I}$ is calculated by $\mathrm{CO} /\left(\mathrm{CO}+2 \mathrm{CO}_{2}\right) \times 100$, where $\mathrm{CO}(\%)$ is the concentration of $\mathrm{CO}$ at the outlet of the reactor and $\mathrm{CO}_{2}(\%)=100-\mathrm{CO}(\%)$.

Moreover, the CRI (Coke Reactivity Index: the percentage of weight loss to the original coke mass after reaction under $\mathrm{CO}_{2}$ at $1100^{\circ} \mathrm{C}$ for $2 \mathrm{~h}$ ) and CSR (Coke Strength after Reaction: percentage of coke mass retained on a sieve with $9.5 \mathrm{~mm}$ apertures to the mass of reacted coke sample after 600 revolutions in the I-type drum tester ${ }^{11)}$ were measured. CRI represents the reactivity of lump coke at a relatively high temperature and is therefore influenced by the pore structure as well as the chemical reactivity of coke.

In addition to the two industrial methods described above, the reactivity of coke was measured using TGA (thermogravimetric analysis). The instrument used was a Shimazu TG-50. Samples were crushed to between 150 and $300 \mu \mathrm{m}$. About $5 \mathrm{mg}$ of the sample was inserted into the sample cell of the TGA and heated from room temperature to the desired reaction temperature in a nitrogen atmosphere, at a heating rate of $10^{\circ} \mathrm{C} \mathrm{min}{ }^{-1}$. The temperature was then maintained and the gas was changed to a reaction gas, while the reaction rate was obtained through weight loss of up to $10 \%$. The reaction temperatures were 1000 to $1150^{\circ} \mathrm{C}$ and the reaction gas composition was $\mathrm{CO}_{2} / \mathrm{CO}=$ $100 / 0,50 / 50$ and 20/80. The gas flow rate was $50 \mathrm{~cm}^{3} \mathrm{~min}^{-1}$. This experiment was conducted for the cokes of Tests 1 and 6 respectively.

Furthermore, a cylindrical coke sample (of diameter $10 \mathrm{~mm}$, length $15 \mathrm{~mm}$ ) cut out of a lump coke was examined using the TGA. The sample was heated from room temperature to $1150^{\circ} \mathrm{C}$ in a $\mathrm{CO}_{2} / \mathrm{CO}=50 / 50$ atmosphere at a heating rate of $10^{\circ} \mathrm{C} \mathrm{min}^{-1}$ and the weight loss was recorded as a function of temperature. This experiment was conducted for the cokes of Tests 1 and 3 respectively.

\section{(3) Coke Porosity}

The coke samples of Tests 1, 2 and 3 were crushed to between 0.84 and $1.68 \mathrm{~mm}$ and the coke porosity was then measured using a mercury porosimeter (FISONS, POROSIMETER2000).

\section{(4) Ca Distribution}

The distribution of $\mathrm{Ca}$ in coke and coal was analyzed using the EPMA technique. The cross-section of the coke samples (Tests 1 and 3) and the lumps of coals B and F were analyzed.

\subsection{Results and Discussion}

\subsubsection{Effect of Alkaline Earth Metal Compound Addition on Coke Reactivity}

Figure 4 shows the relationship between the addition rate of the alkaline earth metal and the JIS coke reactivity index. Here the addition rate of the alkaline earth metal is described as the mole of the added alkaline earth metal per unit mole of carbon in coke. It is clear that the catalytic effects of the alkaline earth metal is in the order of $\mathrm{Sr}>\mathrm{Ca}>$ 


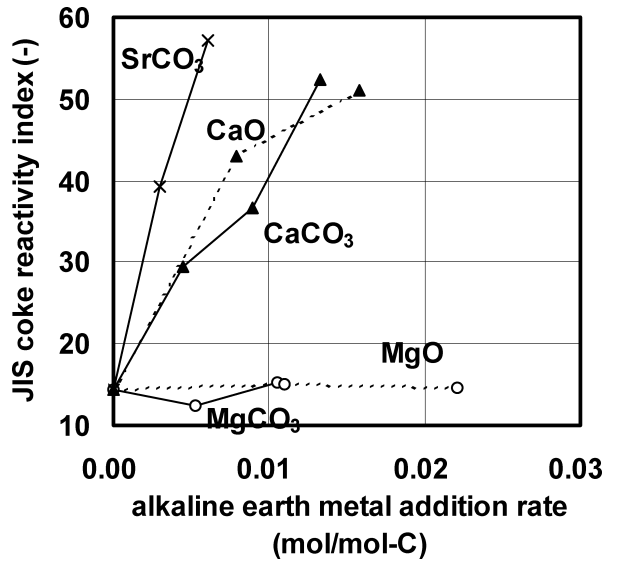

Fig. 4. The relationship between the addition rate of the alkaline earth metal and the JIS coke reactivity index.

Table 3. Effect of Ca-rich coal addition on coke quality.

\begin{tabular}{|l|c|c|c|c|c|}
\hline & Coal F (\%) & DI $^{150}{ }_{15}$ & CRI & CSR & JIS R $_{\mathrm{e}}$ \\
\hline Test 1 & 0 & 84.5 & 23.3 & 66.8 & 6.6 \\
\hline Test 2 & 10 & 84.0 & 24.8 & 68.0 & 39.0 \\
\hline Test 3 & 20 & 81.8 & 33.2 & 58.6 & 41.8 \\
\hline
\end{tabular}

$\mathrm{Mg}$ and that the addition of $\mathrm{MgCO}_{3}$ or $\mathrm{MgO}$ showed no catalytic effects. Coal contains little $\mathrm{Sr}$ and there are no reasonably priced $\mathrm{Sr}$ compounds that can be used in large quantities in the steel industry. On the other hand, large amounts of $\mathrm{CaCO}_{3}$ and $\mathrm{CaO}$ are already used in the ironmaking process as raw materials and also there are some coals rich in $\mathrm{Ca}$. Therefore, $\mathrm{Ca}$ is considered to be promising as a catalyst for enhancing the reactivity of blast furnace coke.

\subsubsection{Effect of Ca-rich Coal Addition on Coke Quality}

(1) JIS Coke Reactivity Index and CRI

Table 3 shows the results of Tests 1 to 3 . It is clear that the JIS coke reactivity index increases considerably with the addition of coal F (Ca-rich coal).

Figure 5 shows the relationship between the blending ratio of non-caking coals (D, E and F) and the JIS coke reactivity index. The JIS coke reactivity index increases with increasing the blending ratio of coal $\mathrm{F}$ (Ca-rich coal), but tends to level off as the blending ratio increases. An increase in the blending ratio of coals D does not, meanwhile, increase the JIS coke reactivity index, although the catalytic effect of $\mathrm{Ca}$ in coal $\mathrm{F}$ is considered to do so. The reason why the JIS coke reactivity index for the blended coal containing coal E is higher than that for the blended coal containing coal D is considered to be because the rank of coal $\mathrm{E}$ is lower than that of coal D, which might lead to the formation of a more reactive coke texture.

Figure 6 shows that CRI increases with increasing the blending ratios of coals $\mathrm{D}, \mathrm{E}$ and $\mathrm{F}$. When maintaining a blending ratio of $10 \%$, the CRI for the blended coals containing coals $\mathrm{E}$ and $\mathrm{F}$ exceeds that of the blended coal containing coal D. It is interesting that despite the far larger JIS coke reactivity index for the blended coal containing coal $\mathrm{F}$ than that for the blended coal containing coal E, the CRI for both blended coals are close. This is considered to be because the CRI is greatly influenced by the pore structure in the coke and the blending of coal E with the lower coal rank

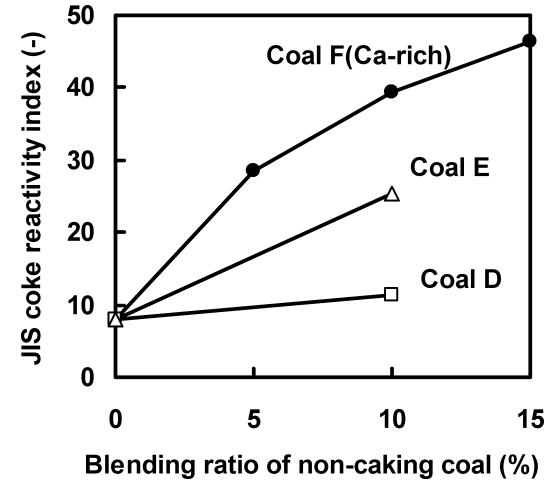

Fig. 5. The relationship between the blending ratio of non-caking coals and the JIS coke reactivity index.

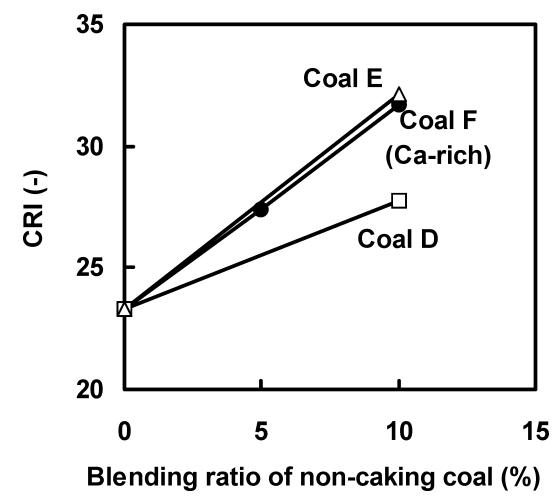

Fig. 6. The relationship between the blending ratio of non-caking coals and CRI.

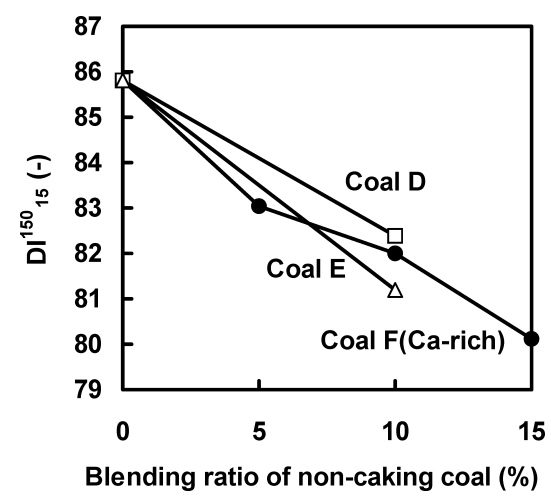

Fig. 7. The relationship between the blending ratio of non-caking coals and $\mathrm{DI}^{150}{ }_{15}$.

leads to the formation of more porous coke structure.

(2) Coke Strength (DI ${ }_{15}^{150}$ and CSR)

Figure 7 shows that the $\mathrm{DI}^{150}{ }_{15}$ decreases with increasing the blending ratio of coals D, E and F. Figure 8 shows that CSR decreases with increasing the blending ratio of coals $\mathrm{D}, \mathrm{E}$ and $\mathrm{F}$. When maintaining a blending ratio of $10 \%$, the CSR for the blended coals containing coals $\mathrm{E}$ and $\mathrm{F}$ is lower than that for the blended coal containing coal D.

\section{(3) Coke Reactivity Measured with TGA}

Figures 9-11 show the relationship between the reaction temperature and rate, measured with TGA. The JIS coke reactivity index for the base coke (Test 1 , produced from the blended coal without coal F (Ca-rich coal)) and the Ca-rich 


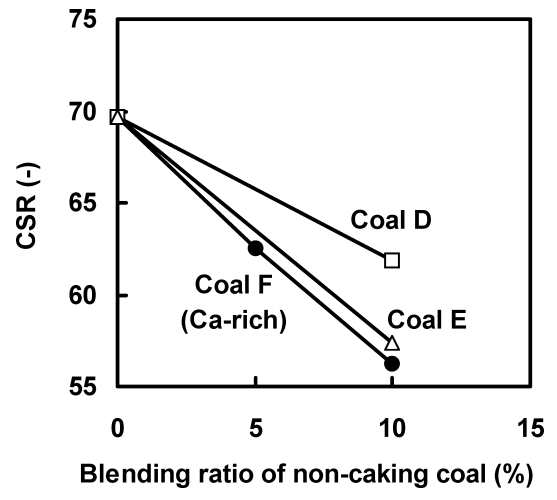

Fig. 8. The relationship between the blending ratio of non-caking coals and CSR.

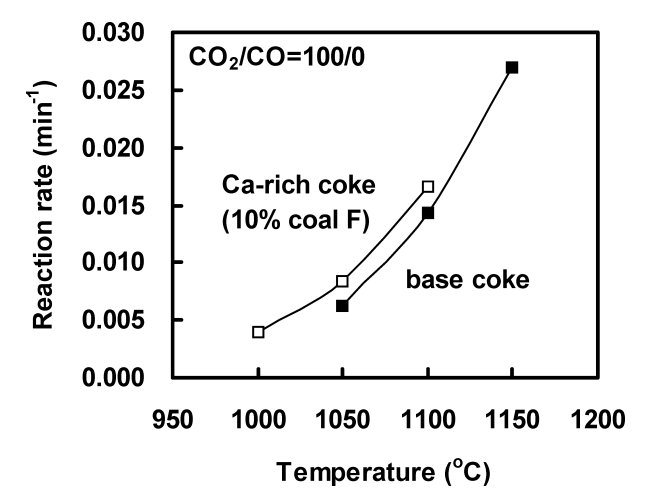

Fig. 9. The relationship between reaction temperature and rate $\left(\mathrm{CO}_{2} / \mathrm{CO}=100 / 0\right)$.

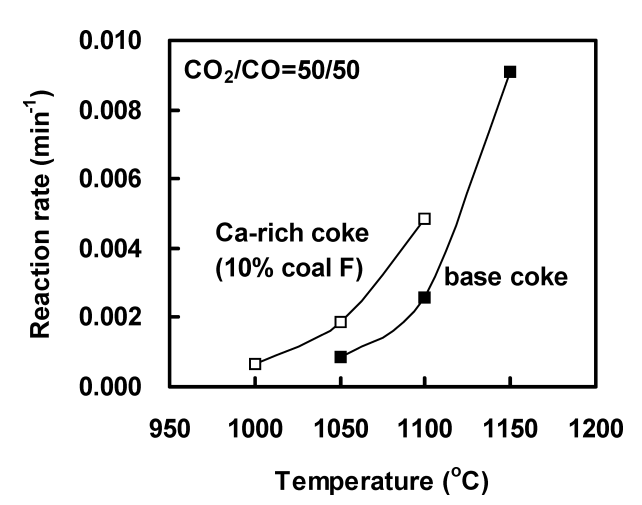

Fig. 10. The relationship between reaction temperature and rate $\left(\mathrm{CO}_{2} / \mathrm{CO}=50 / 50\right)$.

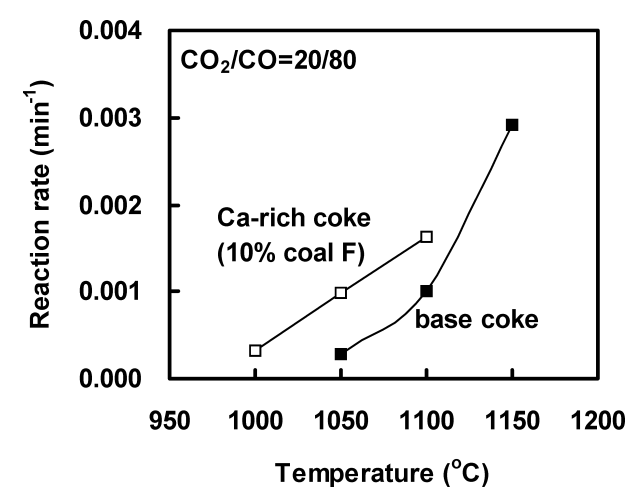

Fig. 11. The relationship between reaction temperature and rate $\left(\mathrm{CO}_{2} / \mathrm{CO}=20 / 80\right)$.

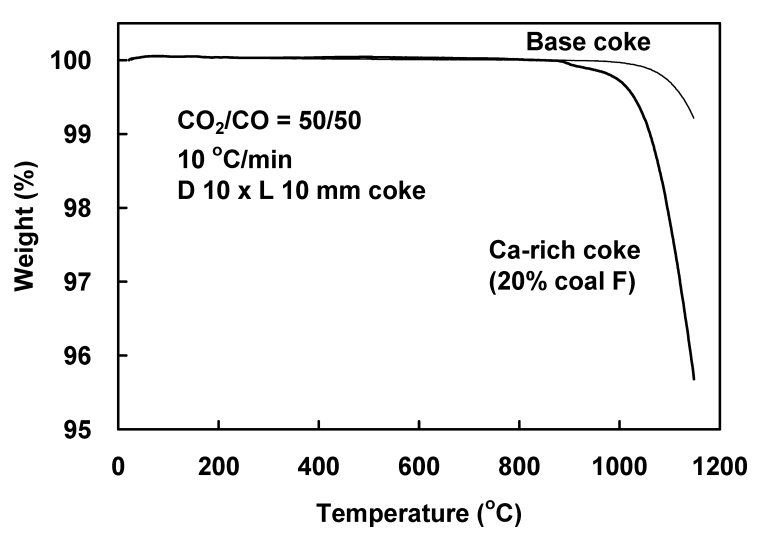

Fig. 12. The weight loss of a cylindrical coke sample in $\mathrm{CO}_{2} / \mathrm{CO}=50 / 50$.

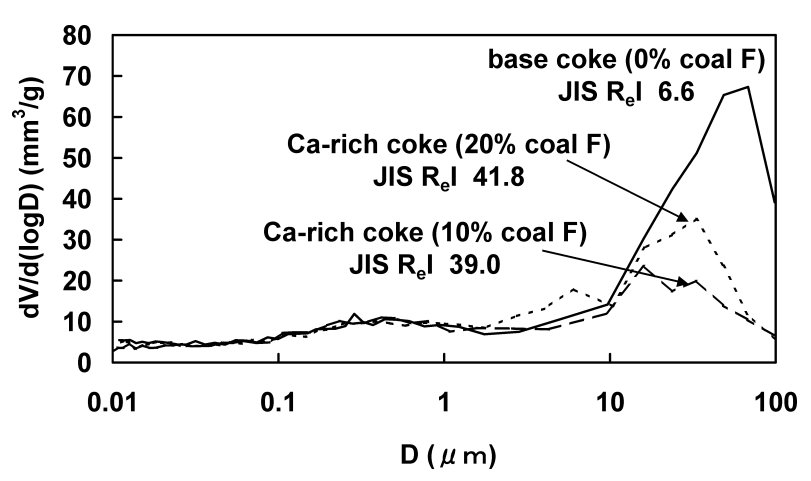

Fig. 13. The distribution of porosity measured by the mercury porosimeter.

coke (Test 6, produced from the blended coal containing $10 \%$ of coal F) are 6.6 and 39.4 respectively. It is clear that the reaction rate of the Ca-rich coke $(10 \%$ coal F) is higher than that of the base coke for any test temperature and any test atmosphere. In addition, in an atmosphere of $\mathrm{CO}_{2} / \mathrm{CO}=$ $20 / 80$ and $50 / 50$, closely resembling that of the thermal reserve zone in a blast furnace, the reaction rate of the Carich coke $(10 \%$ coal $\mathrm{F})$ is more than double that of the base coke. The difference in the reaction rate between the base and Ca-rich coke ( $10 \%$ coal F) is remarkable in an atmosphere of relatively high $\mathrm{CO}$ concentration. The Ca-rich coke produced by blending coal $\mathrm{F}$ is considered to be suitable for decreasing the temperature of the thermal reserve zone in a blast furnace.

Figure 12 shows the weight loss of the base coke (Test 1) and the Ca-rich coke (Test 3, produced from the blended coal containing $20 \%$ of coal F). It is clear that the Ca-rich coke starts to lose weight at a lower temperature than that at which the base coke does likewise.

\section{(4) Porosity}

Figure 13 shows the distribution of porosity measured using the mercury porosimeter for the base coke (Test 1) and the cokes produced from blended coals containing $10 \%$ of coal F (Test 2) or $20 \%$ of coal F (Test 3). It is clear that the pore volume for the Ca-rich coke (10 or $20 \%$ coal F) does not exceed that of the base coke, suggesting that the high JIS coke reactivity index of the Ca-rich coke produced from blended coals containing coal $\mathrm{F}$ could not be attributed to the porosity. 
(a)

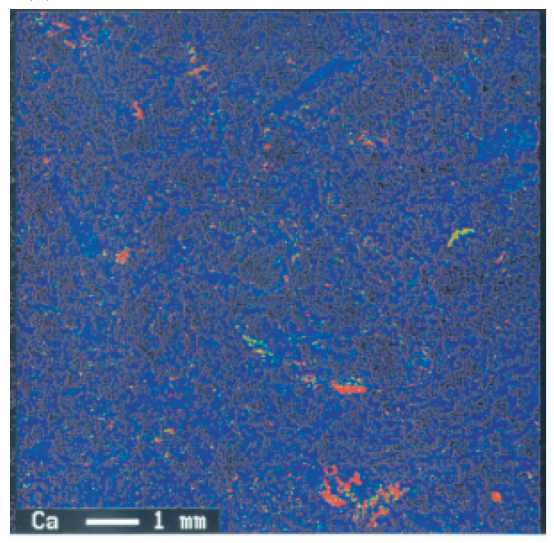

(c)

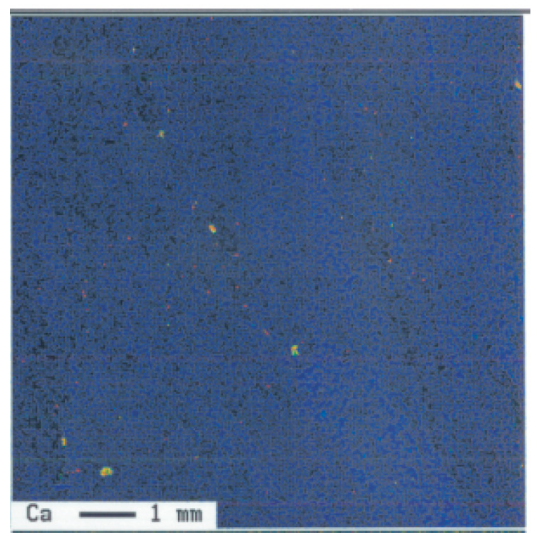

(b)

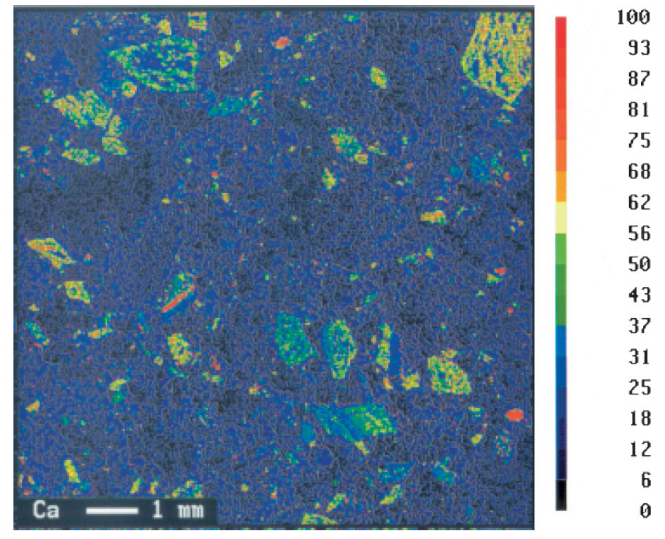

(d)

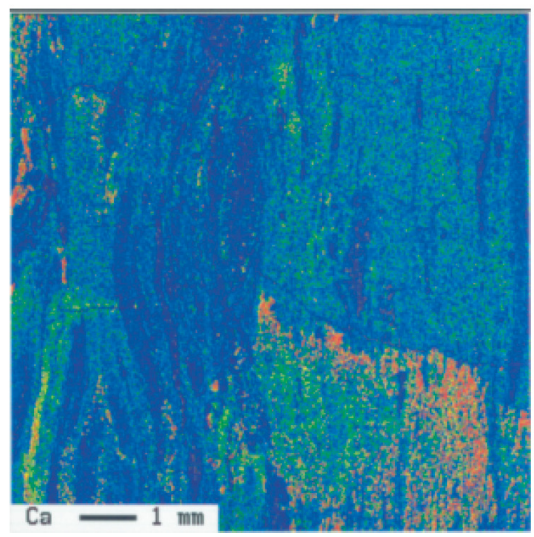

Fig. 14. (a) The distribution of $\mathrm{Ca}$ for the base coke (Test 1). (b) The distribution of Ca for the Ca-rich coke (Test 3, 20\% coal F). (c) The distribution of Ca for a lump of coals B. (d) The distribution of Ca for a lump of coal F (Ca-rich coal).

\section{(5) Ca Distribution}

Figures 14(a) and 14(b) show the distribution of $\mathrm{Ca}$ as determined using EPMA for the base coke (Test 1) and the Ca-rich coke (Test 3, produced from blended coal containing $20 \%$ of coal F). A large number of particles of size around $1 \mathrm{~mm}$ and containing condensed $\mathrm{Ca}$ are observed in the Ca-rich coke and these are considered to be derived from coal $\mathrm{F}$ particles.

Figures 14(c) and 14(d) show the distribution of $\mathrm{Ca}$ in a lump of coals $\mathrm{B}$ and $\mathrm{F}$ respectively. The fine dispersion of $\mathrm{Ca}$ in coal $\mathrm{F}$ and the existence of a Ca-rich 'band' is clear. The reason for the high JIS coke reactivity index of the coke produced from the blended coal containing coal F may be attributed to the finely dispersed level of $\mathrm{Ca}$ in coal $\mathrm{F}$. Further work is necessary concerning the difference in the mode of occurrence of $\mathrm{Ca}$ between the coke produced from blending coal containing coal $\mathrm{F}$ (Ca-rich coal) and the coke produced by adding $\mathrm{Ca}$ compounds such as $\mathrm{CaCO}_{3}$ and $\mathrm{CaO}$ to coal.

\section{Production of Ca-rich Coke in a Commercial Scale Coke Oven}

\subsection{Investigation into the Coal Blend}

When producing Ca-rich coke by blending a Ca-rich non-caking coal in a commercial scale coke oven, the blending ratio of the SCC, low rank and slightly caking coals, should be reduced, in order to maintain the strength of coke above a certain level. On the other hand, any decrease in the blending ratio of the SCC may result in a corresponding decrease in coke reactivity. Consequently, it is important to investigate the possibility of producing the coke with a reactivity higher than that of normal coke and with virtually equivalent strength. Four kinds of blended coals were prepared as shown in Table 4 . The coals were crushed to $-3 \mathrm{~mm} 78 \%$ and the moisture of the coal was $4 \%$. The coals were then charged in a steel box at a bulk density of $800 \mathrm{dry}-\mathrm{kg} / \mathrm{m}^{3}$ before being carbonized in the test oven. The results (Table 4) show that the coke produced in Test 12 shows a higher JIS coke reactivity index than the base coke (Test 10) and that the DI ${ }_{15}^{150}$ and CSR of Test 12 coke is close to or higher than that of the base coke. Therefore, the potential to produce coke of high reactivity and strength by blending Ca-rich coal and adjusting the blend composition has been proved.

\subsection{Production Test of Ca-rich Coke in a Commercial Scale Coke Oven at Kimitsu Works}

Based on the previous fundamental studies, production tests of Ca-rich coke were conducted in a commercial scale coke oven (Nippon Steel Chemical Co.) at the Kimitsu works, by blending 5-7\% of coal $\mathrm{F}$ (Ca-rich coal). The blending ratio of SCC was $19-29 \%$ as compared to $44 \%$ for normal coke production. As shown in Table 5, a coke of high reactivity and strength was then successfully produced 
Table 4. The coal blending composition, coal properties and coke quality in producing the Ca-rich coke in a test coke oven.

\begin{tabular}{|c|c|c|c|c|c|}
\hline & \multicolumn{4}{|c|}{ Test } \\
\hline & & 10 & 11 & 12 & 13 \\
\hline \multirow{2}{*}{$\begin{array}{l}\text { Coal } \\
\text { blend }\end{array}$} & coal F (Ca-rich) (\%) & 0.0 & 7.5 & 7.5 & 5.0 \\
\hline & SCC ratio (\%) (incl. coal F) & 30 & 16 & 11 & 24 \\
\hline \multirow{4}{*}{$\begin{array}{c}\text { Coal } \\
\text { property }\end{array}$} & VM (mass \% db) & $\overline{27.2}$ & 25.5 & 25.0 & 26.5 \\
\hline & Ash (mass \% db) & 9.2 & 9.0 & 9.0 & 9.1 \\
\hline & $\begin{array}{l}\text { Total dilatation } \\
\text { (vol. \%) (calc.) }\end{array}$ & 90 & 100 & 105 & 94 \\
\hline & $\begin{array}{l}\text { Maximum fluidity } \\
\text { (log MF/ddpm) (calc.) }\end{array}$ & 2.46 & 2.38 & 2.42 & 2.39 \\
\hline \multirow{3}{*}{$\begin{array}{l}\text { Coke } \\
\text { quality }\end{array}$} & $\mathrm{DI}^{150}{ }_{15}(-)$ & 86.2 & 85.3 & 86.0 & 85.0 \\
\hline & $\operatorname{CSR}(-)$ & 51.0 & 48.1 & 53.7 & 42.6 \\
\hline & JIS $R_{e} I(-)$ & 17.0 & 33.9 & 37.3 & 31.2 \\
\hline
\end{tabular}

Table 5. The coal blending composition, coal properties and coke quality in producing the Ca-rich coke in a commercial scale coke oven.

\begin{tabular}{|c|c|c|c|c|c|}
\hline & \multicolumn{2}{|c|}{ Kimitsu } & \multicolumn{2}{|c|}{ Muroran } \\
\hline & & base & Ca-rich & base & Ca-rich \\
\hline \multirow{2}{*}{$\begin{array}{l}\text { Coal } \\
\text { blend }\end{array}$} & coal F (Ca-rich) (\%) & 0 & $5-7$ & 0 & 8 \\
\hline & SCC ratio (\%) (incl. coal F) & 44 & $19-29$ & 42 & 45 \\
\hline \multirow{4}{*}{$\begin{array}{c}\text { Coal } \\
\text { property }\end{array}$} & VM (mass \% db) & 28.5 & $26.1-27.3$ & 27.6 & 28.7 \\
\hline & Ash (mass \% db) & 9.0 & $8.6-8.7$ & 9.2 & 8.9 \\
\hline & $\begin{array}{l}\text { Total dilatation } \\
\text { (vol.\%) (calc.) }\end{array}$ & 56 & $69-76$ & 49 & 81 \\
\hline & $\begin{array}{l}\text { Maximum fluidity } \\
\text { (log MF/ddpm) (calc.) }\end{array}$ & 2.18 & 2.12-2.15 & 1.74 & 2.30 \\
\hline \multirow{3}{*}{$\begin{array}{l}\text { Coke } \\
\text { quality }\end{array}$} & $\mathrm{DI}^{150}{ }_{15}(-)$ & 85.5 & $85.6-86.2$ & 85.0 & 84.9 \\
\hline & CSR (-) & 55.0 & $54.7-63.0$ & 61.7 & 60.6 \\
\hline & JIS $R_{e} I(-)$ & 15.8 & $33.3-39.4$ & 15.1 & 45.9 \\
\hline
\end{tabular}

in a commercial scale coke oven.

\section{Muroran No. 2 BF Operation with Ca-rich Highly Reactive Coke}

\subsection{Long-term Production Test of Ca-rich Coke in a Commercial Scale Coke Oven at Muroran Works}

The next step involved producing Ca-rich coke in the commercial scale coke oven (Hokkai Iron \& Coke Corp.) at the Muroran works from June to September of 2002 with all the cokes being used in the Muroran No.2 blast furnace. The typical coal blend during this period is shown in Table 5. Here, the blending ratio of SCC in Ca-rich coke production was found to be the same as that used in normal coke production. However, caking coals with high total dilatation were chosen, meaning the average total dilatation of the blended coal was higher than that for base coke production. During the production of Ca-rich coke, the blending ratios of coal F and SCC were $8 \%$ and $45 \%$ respectively. As shown in Table 5, a coke of high reactivity and strength was produced for a consecutive period exceeding two months.

Figure 15 shows the relationship between the $\mathrm{DI}^{150}{ }_{15}$ and JIS coke reactivity index in terms of coke produced on a commercial scale. Blending Ca-rich coal and adjusting the coal blend composition results in the production of highly reactive coke which maintains its strength, $\mathrm{DI}^{150}{ }_{15}$.

Figure 16 shows the relationship between the Ca content in coke and the JIS coke reactivity index. The reactivity increases with increasing $\mathrm{Ca}$ content in the coke.

\subsection{The Evaluation of Ca-rich Highly Reactive Coke Using the Adiabatic Blast Furnace Simulator}

Before the Ca-rich coke was tested in a commercial scale blast furnace, the effect of the Ca-rich coke on the reduction behavior of sinter was studied using the adiabatic blast

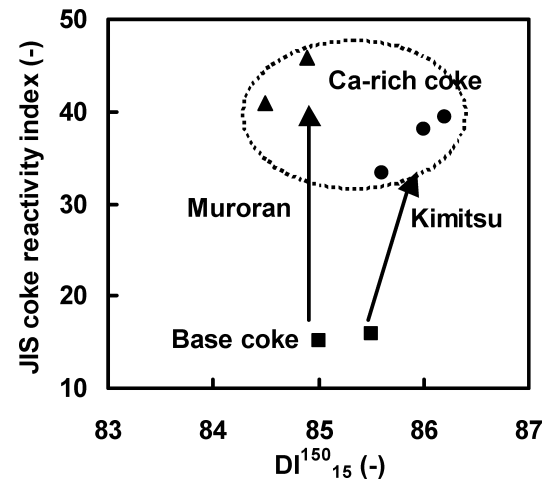

Fig. 15. The relationship between $\mathrm{DI}^{150}{ }_{15}$ and the JIS coke reactivity index.

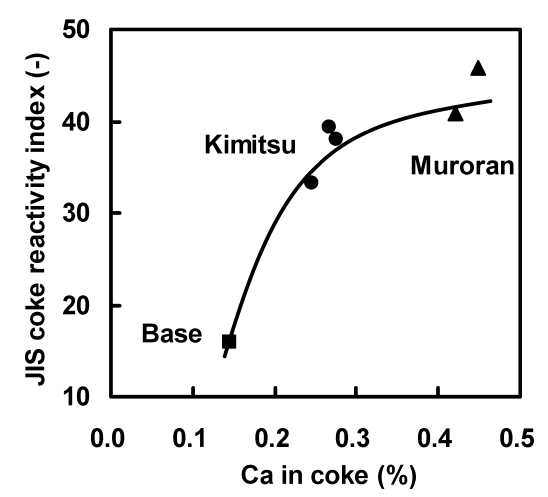

Fig. 16. The relationship between Ca content in coke and the JIS coke reactivity index.

furnace simulator. ${ }^{1,12)}$ Normal coke (JIS $\left.\mathrm{R}_{\mathrm{e}} \mathrm{I}=15.8\right)$ and Carich highly reactive coke (produced from blended coals including $5 \%$ of coal $\mathrm{F}$; JIS $\mathrm{R}_{\mathrm{e}} \mathrm{I}=33.8$ ) produced in a commercial scale coke oven at Kimitsu works, and sinter (Table 6) produced at the Kimitsu works were used in this test. 
Table 6. The chemical composition of the sinter used.

Sinter (mass \%)
\begin{tabular}{|c|c|c|c|c|}
\hline T.Fe & FeO & $\mathrm{CaO}$ & $\mathrm{SiO}_{2}$ & $\mathrm{Al}_{2} \mathrm{O}_{3}$ \\
\hline 57.36 & 6.08 & 10.11 & 5.18 & 1.86 \\
\hline
\end{tabular}

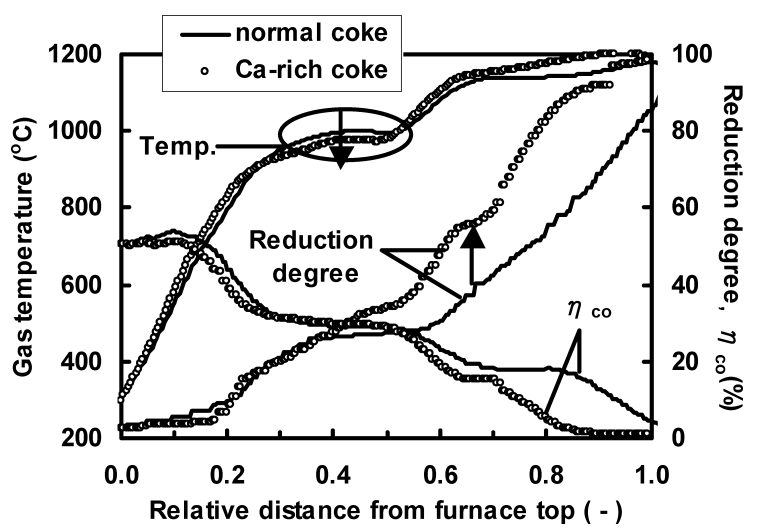

Fig. 17. Effect of Ca-rich coke on the temperature and sinter reduction behavior in the adiabatic blast furnace simulator.

The experimental conditions were as follows: RAR (reducing agent rate); $495.8 \mathrm{~kg} / \mathrm{t}-\mathrm{p}(\mathrm{PCR}=160 \mathrm{~kg} / \mathrm{t}-\mathrm{p})$, Bosh gas; $1328 \mathrm{Nm}^{3} / \mathrm{t}-\mathrm{p}, \mathrm{CO} ; 37.5 \%, \mathrm{H}_{2} ; 8.0 \%, \mathrm{~N}_{2} ; 54.5 \%$.

As shown in Fig. 17, although the same sinter was used in the experiments, the Ca-rich highly reactive coke decreased the temperature of the thermal reserve zone and increased the reduction degree of the sinter. Based on these results, we decided to use Ca-rich coke in a commercial scale blast furnace.

\subsection{Muroran No. 2 BF Operation with Ca-rich Highly Reactive Coke}

As stated previously, Ca-rich coke was produced in the commercial scale coke oven at the Muroran works from June to September of 2002 and all the cokes were used in the Muroran No. 2 blast furnace (Hokkai Iron \& Coke Corp.). During this period, the productivity of pig iron was between 1.89 and $2.08\left(\right.$ ton $/ \mathrm{d} / \mathrm{m}^{3}$ ) and the PCR (pulverized coal injection ratio) was between 146 and 154 (kg-coal/tonpig iron). The coke strength was maintained at the desired value and no remarkable changes in the gas permeability in the blast furnace were observed. As shown in Fig. 18, the RAR decreases with increasing the blending ratio of $\mathrm{Ca}-$ rich coal. Figure 19 shows the relationship between the $\mathrm{Ca}$ rich coal blending ratio and the RAR. Due to the changes in the chemical composition of the sinter during the test period, the test data were plotted depending on the level of sinter $\mathrm{FeO}$ and $\mathrm{Al}_{2} \mathrm{O}_{3}$. This analysis also shows that RAR decreases with increasing the blending ratio of $\mathrm{Ca}$-rich coal.

\section{Conclusions}

A method to produce 'lump' coke of high reactivity and strength was investigated in order to improve blast furnace reaction efficiency. The following findings were obtained.

(1) The addition of $\mathrm{Ca}$ compounds to coal prior to carbonization considerably increases the reactivity of the resultant coke at a low temperature range, in the thermal reserve zone of a blast furnace.
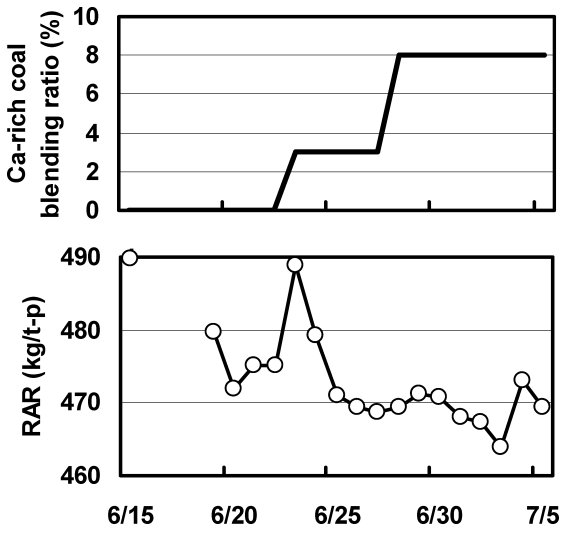

Fig. 18. Changes in RAR and Ca-rich coal blending ratio.

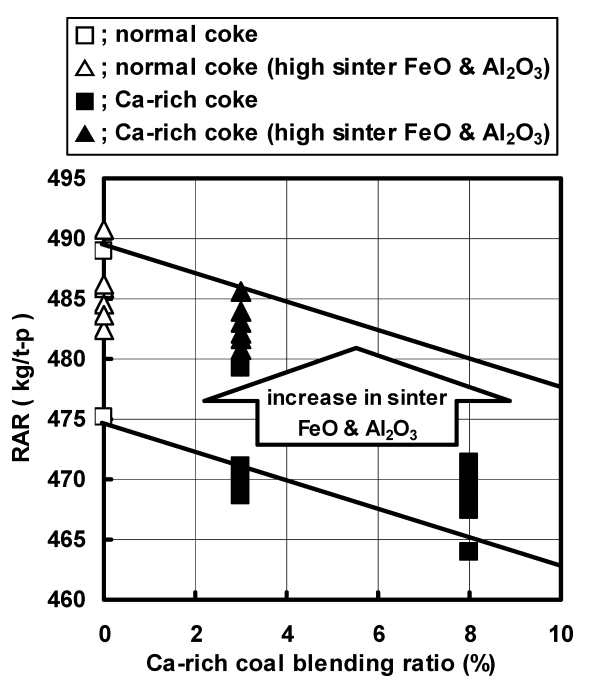

Fig. 19. Effect of Ca-rich coal blending ratio on RAR.

(2) A strong, highly reactive 'lump' form of coke can be produced by adding a Ca-rich non-caking coal and adjusting the coal blend composition. The Ca-rich coke was successfully produced in the commercial scale coke ovens both at Kimitsu and Muroran works.

(3) A laboratory scale experiment showed that the Ca-rich coke caused the temperature of the thermal reserve zone in a blast furnace to decrease. By using the Ca-rich coke in the Muroran No. 2 blast furnace, the reducing agent rate decreased by $10 \mathrm{~kg} / \mathrm{t}-\mathrm{p}$.

This technology, producing coke of high reactivity and strength through catalyst addition, is promising as a means of improving the reaction efficiency of a blast furnace. In order to successfully commercialize this technology, we will continue to further study catalyst substances other than Ca-rich coal and alternative methods of adding the catalyst to the coke, such as the 'post-addition of catalyst to coke' method.

\section{REFERENCES}

1) M. Naito, A. Okamoto, K. Yamaguchi, T. Yamaguchi and Y. Inoue: Tetsu-to-Hagané, 87 (2001), 357.

2) N. Miyasaka and S. Kondo: Tetsu-to-Hagané, 54 (1968), 1427.

3) T. Nakayama, K. Anan, M. Shirakawa, Y. Inoue and M. Naito: CAMP-ISIJ, 6 (1993), 128.

4) N. Morishita, M. Higuchi, Y. Inoue, T. Haga, Y. Matsuoka, N. Konnno, S. Matsuzaki, M. Naito and T. Deno: The 54th Committee 
ISIJ International, Vol. 45 (2005), No. 3

(Ironmaking), the Japan Society for the Promotion of Science (JSPS), Rep. No. 2048, (1995).

5) D. Vogt, J. M. Duchene, J. N. Rouzaud and D. Isler: AIME 50th Ironmaking Conf. Proc., AIME, Washington D.C., (1991), 225.

6) T. Miyagawa: J. Fuel Soc. Jpn., 58 (1979), 940.

7) Chemistry and Physics of Carbon, Vol. 4, ed. by P. L. Walker, Jr., Marcel Dekker, New York, (1968), 287.

8) Fundamental Issues in Control of Carbon Gasification Reactivity, ed. by J. Lahaye and P. Ehrburger, Kluwer Academic Publishers,
Dordrecht, (1991), 383

9) K. Shiraishi, T. Yamaguchi, T. Nishi and T. Arima: Coke Circular Jpn., 30 (1981), 239.

10) Japanese Industrial Standard JIS K 2151(1993): Methods for Testing of Coke.

11) N. Nakamura, Y. Togino and M. Tateoka: Ironmaking Steelmaking, 5 (1978), 1.

12) M. Naito, M. Nakano and S. Nomura: 3rd Int. Conf. on Science and Technology of Ironmaking Proc., VDEh, Düsseldorf, (2003), 539. 